Article - Biological and Applied Sciences

\title{
In Vitro Organogenesis from Root Explants of Passiflora miniata Mast., an Amazonian Species with Ornamental Potential
}

\author{
Paula Pinheiro de Carvalho ${ }^{1}$ \\ https://orcid.org/0000-0001-8443-9050
}

Camila Aparecida Antoniazzi ${ }^{1}$

https://orcid.org/0000-0002-5566-8396

Rodrigo Brito de Faria ${ }^{1}$

https://orcid.org/0000-0003-1438-866X

Ilio Fealho de Carvalho'

https://orcid.org/0000-0003-1657-348X

Diego Ismael Rocha ${ }^{2}$

https://orcid.org/0000-0001-6683-0961

Maurecilne Lemes da Silva ${ }^{{ }^{*}}$

https://orcid.org/0000-0001-6928-285X

${ }^{1}$ State of University of Mato Grosso, Science Faculdad of Biological, Agronomy and Health, Biology Department, Tangará of Serra, Mato Grosso, Brazil. ${ }^{2}$ Federal University of Goiás, Institute of Biological Sciences, Jataí, Goiás, Brazil.

Received: 2018.03.08; Accepted: 2019.03.18.

${ }^{*}$ Correspondence: maurecilne@gmail.com; Tel.: +55-65-9909-3266

\section{HIGHLIGHTS}

- Shoot organogenesis was induced from root explants of Passiflora miniata

- Thidiazuron (TDZ) was the best cytokinin for differentiation of adventitious shoots

- $\quad 6.8 \mu \mathrm{M}$ TDZ was the best concentration to induce adventitious shoots

ABSTRACT: The present study reports a shoot organogenesis-based system for in vitro regeneration of Passiflora miniata, an Amazonia passion fruit species. Root segments were cultured in Murashige and Skoog (MS) medium supplemented with different concentrations 
(range 2-9 $\mu \mathrm{M}$ ) of 6-benzyladenine (BA); thidiazuron (TDZ) or kinetin (KIN). Plant growth regulators were not added to the control treatment. Root explants have showed a high regenerative potential. After 30 days of in vitro culture, the root explants showed several shoots formed direct and indirectly. TDZ provided the best response in the differentiation adventitious shoots, mainly in the presence of $6.8 \mu \mathrm{M}$. The cytokinins BA and KIN responded producing a reduced number of shoots. After 120 days, rooted regenerated plants were transferred to a greenhouse for acclimatization. This regeneration system opens new perspectives for micropropagation and conservation of this wild Amazonic passion fruit species.

Key words: Morphogenesis, Ornamental passion fruit, Plant regeneration, Root explant, Shoot organogenesis, Thidiazuron.

\section{INTRODUCTION}

The species of the genus Passiflora have stood out as potential plants for use in the flower market, thanks mainly to the beauty and exuberance of its flowers that vary largely with strong, bright to mild colors [1]. The ornamental potential of passion fruits is practically unexploited in Brazil, although it has been considered an origin and diversity center, concentrating approximately 140 species in which, 60\% (84 species) are considered endemic [2]. In the Northern-Hemisphere countries, over 400 Passiflora hybrids for ornamental purposes have been registered [3]. Recently, in a partnership with other organizations, Brazilian Agricultural Research Corporation (Embrapa) has also produced passion fruit hybrids with this purpose [4].

Given the above scenario and the recognized economic importance of Passiflora species, studies applied to micropropagation and biotechnology of Passiflora species, via tissue culture, have been increasingly undertaken worldwide. Regeneration protocols have been established from different types of explants, e.g. leaf, hypocotyl, root, nodal and intermodal segments and zygotic embryos [5-13]. At present, root segments have been adopted as explant source for in vitro regeneration of passion fruit $[14,15,11,16]$; for being easily obtained and maintained under in vitro conditions, in general [17]. In addition, they have shown high regenerative potential in shoot production when compared with other non-meristematic Passiflora explants [18,14]. Passiflora miniata Mast. is a wild species native to the southern Brazilian Amazon that can also be found in Bolivia, Colombia, Peru, Venezuela, and the Guianas [19]. This species has been extensively cultivated erroneously as Passiflora coccinea because of similar characteristics such as bright-red flowers [20]. Studies involving the in vitro regeneration of $P$. miniata have only been published by $[21,13]$, were established a protocol involving somatic embryogenesis and organogenesis using zygotic embryos as explant sources, respectively. In the present study, we report the establishment of a protocol for in vitro regeneration of $P$. miniata via organogenesis from root segments. 


\section{MATERIALS AND METHODS}

Mature seeds of $P$. miniata were collected from wild populations located in Alta Floresta (S 09 99' 67.7" w 56 12'33.6') - MT, Brazil. The tegument of the seeds was removed with a mini vise [22] in order to facilitate the germination. The seeds surface were disinfected in a laminar flow hood by immersion in $70 \%$ ethanol $(\mathrm{v} / \mathrm{v})$ for $2 \mathrm{~min}$, followed by 15 min of immersion in a solution of commercial sodium hypochlorite $2.5 \%(\mathrm{v} / \mathrm{v})$ added with two drops of Tween-20 dispersant $0.1 \%(\mathrm{v} / \mathrm{v})$ per $100 \mathrm{~mL}$ of solution. The seeds were then subjected to 4 consecutive rinses in autoclaved distilled water. Later, seeds were inoculated in $250 \mathrm{~mL}$ flasks containing half-strength Murashige and Skoog medium (MS) [23], and kept under in vitro culture for 30 days. The root segments (average $1 \mathrm{~cm}$ ) were obtained from the seedlings germinated in vitro and used as explants.

Root segments were cultured in medium (MS) containing MS basal salts, MS vitamins, $100 \mathrm{mg} \mathrm{L}^{-1}$ myo-inositol, 3.0\% sucrose (w/v), and 0.8\% agar (w/v) (Acumedia ${ }^{\circledR}$, Michigan). The medium was supplemented with different concentrations $(2.2,3.3,4.4,5.5,6.6,7.7 ; 8.8$ $\mu \mathrm{M})$ of 6-Benzyladenine (BA), (2.2, 3.4, 4.5, 5.6, 6.8, 7.9; $9.0 \mu \mathrm{M})$ Thidiazuron (TDZ) or (2.3; $3.4 ; 4.6 ; 5.8 ; 6.9 ; 8.1 ; 9.2 \mu \mathrm{M}$ ) Kinetin (KIN). The control treatment received no addition of pant growth regulators. The $\mathrm{pH}$ was adjusted to $5.7 \pm 0.1$ prior to autoclaving for $20 \mathrm{~min}$ (121 ${ }^{\circ} \mathrm{C}$ and $1.1 \mathrm{~atm}$ of pressure). The media were poured in sterile Petri crystal polystyrene dishes (90 × $15 \mathrm{~mm}$, J. Prolab, Brazil). The cultures were kept in a growth room under irradiance of $36 \mu \mathrm{mol} \mathrm{m} \mathrm{m}^{-2} \mathrm{~s}^{-1}$ provided by fluorescent lamps at a temperature of $26 \pm 2{ }^{\circ} \mathrm{C}$. Experiments were repeated at least once, and observations were recorded after 30 days.

For rooting, regenerated shoots were separated from the initial explants and transferred to flasks containing MS medium without plant growth regulators and kept under in vitro cultivation for 90 days. After this period, rooted plants were washed in running water and transferred to $300 \mathrm{~cm}^{3}$ plastic cups (one shoot per cup) filled with a commercial substrate (Plantmax®, Paulinia, Brazil).

A completely randomized experimental design was adopted. The experiment consisted of five replicates per treatment, each represented by a Petri dish containing 10 explants. After 30 days of growth, we determined percentage of direct and indirect organogenesis for each growth regulator, the percentage of explants with morphogenic response, the average production of adventitious shoots, the average length of the regenerated seedlings and the number of roots. Data were subjected to analysis of variance (ANOVA) and differences between treatment average were compared by Tukey's test at the $5 \%$ probability level ( $p \leq$ 0.05), using the Sisvar software [24]. Square transformed data of $Y+0.5-S Q R T(Y+0.5)$.

\section{RESULTS AND DISCUSSION}

The development of adventitious shoots in root explants of $P$. miniata began with swelling at the cut surfaces of the explant, following by disruption of the epidermis (Fig. 1A). These organogenic structures rapidly proliferated and developed across the surface of the explants (Fig. 1B). After 30 days of in vitro growth, the root explants showed several shoots formed direct and indirectly (Fig. 1C, D, respectively). 

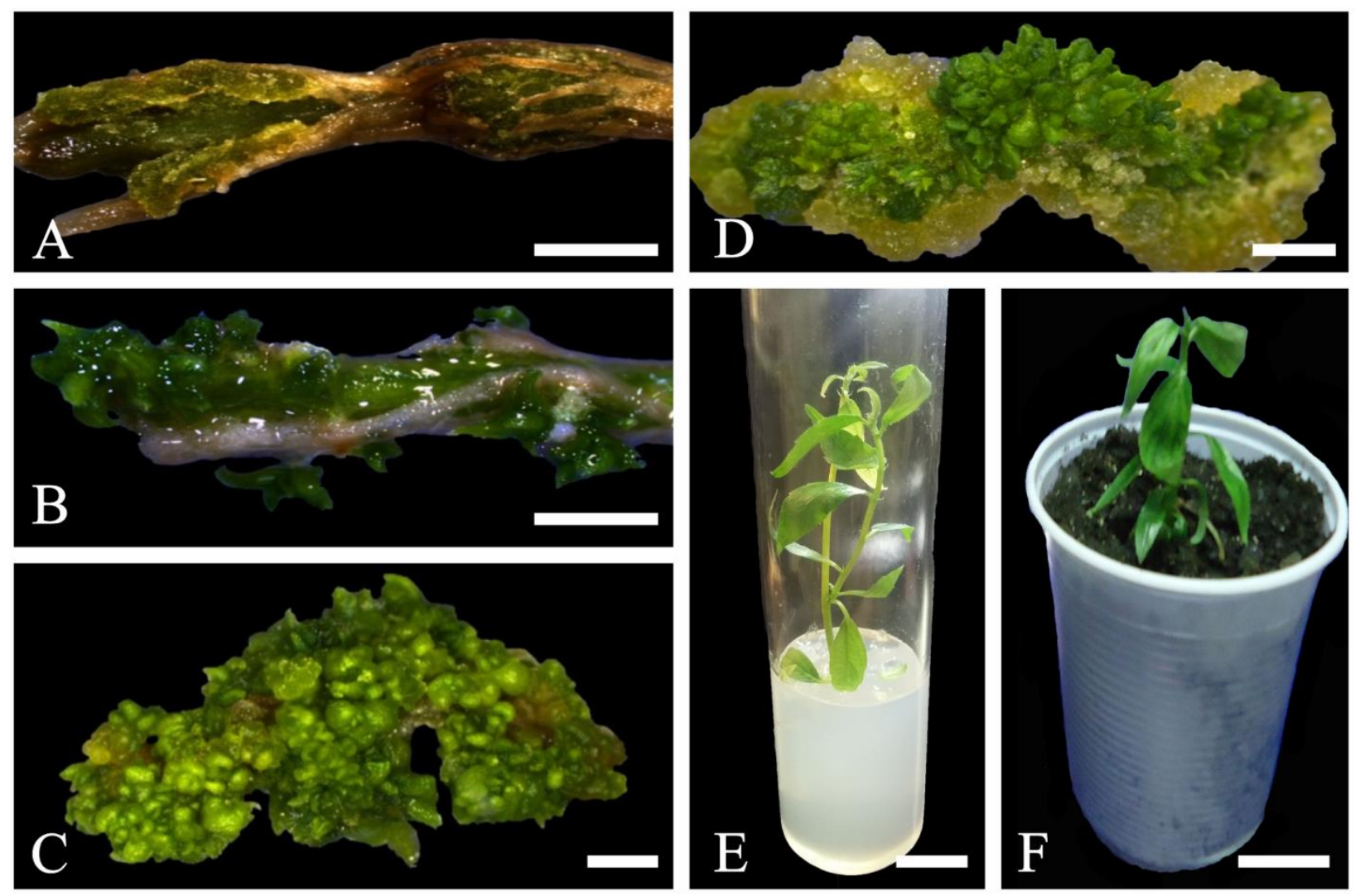

Figure 1. Shoot organogenesis from root segments of $P$. miniata. (A-B) Root segment cultured in medium supplemented with $4.4 \mu \mathrm{M}$ BA showing epidermal disruption $(\mathrm{A})$ and proliferation of organogenic structures throughout the root segments (B). (C) Direct shoot organogenesis $(6.8 \mu \mathrm{M}$ TDZ). (D) Indirect shoot organogenesis (4.4 $\mathrm{M} B \mathrm{BA})$. (E) Elongating regenerated plant. (F) Acclimatized regenerated plant. Bars $=A-D 2.5 \mathrm{~mm} ; \mathrm{E} 10 \mathrm{~mm} ; \mathrm{F} 20 \mathrm{~mm}$.

Successful regeneration protocols based on the use of the root as explant source has been described for several plant species [25-27]. In Passiflora, a protocol using root explants for shoot organogenesis was stablished for $P$. cinicinnata [28,14], $P$. edulis [14,15,29], P. setacea [11] and $P$. suberosa [16]. Organogenesis is a regeneration system based in the formation of unipolar adventitious organs with vascular connection to the original explant $[30,31,32]$. It is also, the predominant morphogenetic pathway observed in Passiflora [33].

The induction of in vitro organogenesis is mainly influenced by endogenous and/or exogenous hormonal signaling which may specify cell identity from gene expression reprogramming required for the cell-fate transition [31,33,32,29]. In the present study, shoots were induced only in the presence of exogenous supplementation of plant growth regulators (Table 1 ). 
Table 1. Organogenesis response of Passiflora miniata root explants after 30 days of in vitro culture with different plant growth regulators (PGRs), quantified as percentage of explants with morphogenetic response, number of shoots per explant, number of regenerated plants per explant and Number of roots per regenerated plant.

\begin{tabular}{|c|c|c|c|c|c|c|}
\hline \multicolumn{3}{|c|}{ PGRs $(\mu \mathrm{M})$} & \multirow{2}{*}{$\begin{array}{c}\text { Explants with } \\
\text { morphogenetic } \\
\text { response (\%) }\end{array}$} & \multirow{2}{*}{$\begin{array}{c}\text { Number of } \\
\text { shoots } \\
\text { per explant }\end{array}$} & \multirow{2}{*}{$\begin{array}{l}\text { Regenerated } \\
\text { plants } \\
\text { per explant }\end{array}$} & \multirow{2}{*}{$\begin{array}{c}\text { Number of roots per } \\
\text { regenerated plant }\end{array}$} \\
\hline BA & TDZ & KIN & & & & \\
\hline- & - & - & $0 \mathrm{c}$ & $0.0 \mathrm{c}$ & $0.0 \mathrm{c}$ & $0.0 \mathrm{~b}$ \\
\hline 2.2 & - & - & $32.0 \mathrm{abc}$ & $0.0 \mathrm{~b}$ & $0.0 \mathrm{c}$ & $0.0 \mathrm{~b}$ \\
\hline 3.3 & - & - & $36.0 \mathrm{abc}$ & $9.0 \mathrm{bc}$ & $2.0 \mathrm{c}$ & $0.0 \mathrm{~b}$ \\
\hline 4.4 & - & - & $44.0 \mathrm{ab}$ & $14.4 \mathrm{~b}$ & $2.0 \mathrm{c}$ & $0.0 \mathrm{~b}$ \\
\hline 5.5 & - & - & $24.0 \mathrm{abc}$ & $0.2 \mathrm{c}$ & $0.0 \mathrm{c}$ & $0.0 \mathrm{~b}$ \\
\hline 6.6 & - & - & $16.0 \mathrm{bc}$ & $0.0 \mathrm{c}$ & $0.0 \mathrm{c}$ & $0.0 \mathrm{~b}$ \\
\hline 7.7 & - & - & $14.0 \mathrm{bc}$ & $0.0 \mathrm{c}$ & $0.0 \mathrm{c}$ & $0.0 \mathrm{~b}$ \\
\hline 8.8 & - & - & $8.0 \mathrm{bc}$ & $0.0 \mathrm{c}$ & $0.0 \mathrm{c}$ & $0.0 \mathrm{~b}$ \\
\hline- & 2.2 & - & $0.0 \mathrm{c}$ & $0.0 \mathrm{c}$ & $0.0 \mathrm{c}$ & $0.0 \mathrm{~b}$ \\
\hline- & 3.4 & - & $24.0 \mathrm{abc}$ & $0.4 \mathrm{c}$ & $0.0 \mathrm{c}$ & $0.0 \mathrm{~b}$ \\
\hline- & 4.5 & - & $20.0 \mathrm{bc}$ & $14.2 b$ & $4.0 \mathrm{~b}$ & $0.4 \mathrm{~b}$ \\
\hline- & 5.6 & - & $40.0 \mathrm{abc}$ & $8.0 \mathrm{bc}$ & $4.0 \mathrm{~b}$ & $0.4 \mathrm{~b}$ \\
\hline- & 6.8 & - & $64.0 \mathrm{a}$ & $38.0 \mathrm{a}$ & $6.0 \mathrm{a}$ & $1.4 \mathrm{a}$ \\
\hline- & 7.9 & - & $12.0 \mathrm{bc}$ & $0.0 \mathrm{c}$ & $0.0 \mathrm{c}$ & $0.0 \mathrm{~b}$ \\
\hline- & 9.0 & - & $8.0 \mathrm{bc}$ & $0.0 \mathrm{c}$ & $0.0 \mathrm{c}$ & $0.0 \mathrm{~b}$ \\
\hline- & - & 2.3 & $0.0 \mathrm{c}$ & $0.0 \mathrm{c}$ & $0.0 \mathrm{c}$ & $0.0 \mathrm{~b}$ \\
\hline- & - & 3.4 & $8.0 \mathrm{bc}$ & $2.0 \mathrm{c}$ & $0.0 \mathrm{c}$ & $0.0 \mathrm{~b}$ \\
\hline- & - & 4.6 & $20.0 \mathrm{bc}$ & $1.0 \mathrm{c}$ & $0.0 \mathrm{c}$ & $0.0 \mathrm{~b}$ \\
\hline- & - & 5.8 & $4.0 \mathrm{bc}$ & $0.0 \mathrm{c}$ & $0.0 \mathrm{c}$ & $0.0 \mathrm{~b}$ \\
\hline- & - & 6.9 & $0.0 \mathrm{c}$ & $0.0 \mathrm{c}$ & $0.0 \mathrm{c}$ & $0.0 \mathrm{~b}$ \\
\hline- & - & 8.1 & $0.0 \mathrm{c}$ & $0.0 \mathrm{c}$ & $0.0 \mathrm{c}$ & $0.0 \mathrm{~b}$ \\
\hline- & - & 9.2 & $0.0 \mathrm{c}$ & $0.0 \mathrm{c}$ & $0.0 \mathrm{c}$ & $0.0 \mathrm{~b}$ \\
\hline
\end{tabular}

Means followed by the same letter in each column are not significantly different from each other according to Tukey's test ( $p \leq 0.05$ ).

TDZ-treatments induced the highest number of adventitious shoots (Fig. 1C), mainly in the presence of $6.8 \mu \mathrm{M}$, averaging 38.0 shoots per explant (Table 1). The cytokinins BA and KIN responded with a reduced number of shoots (Table 1). In addition, in the presence of BA and KIN root explants showed $92 \%$ and $95 \%$ of shoots produced by indirect organogenesis, respectively. Unlike, most of the adventitious shoots were formed directly (52\%) in TDZ-treatments, as observed in Figure 2. For most protocols, MS medium supplemented with BA concentrations range from 2.2 to $8.8 \mu \mathrm{M}$ has been used for shoot bud induction from root explants of passion fruit species $[14,11,16]$. However, few of those studies have tested TDZ [11]). The efficacy of TDZ for inducing direct shoot organogenesis may be related to their reduced susceptibility to enzymatic degradation, relative to naturally occurring 
cytokinins such as aminopurine. It may be also related to the TDZ ability of fulfilling both the cytokinin and auxin requirements during morphogenetic plant process [34-37].

- Direct organogenesis $\quad$ aIndirect organogenesis

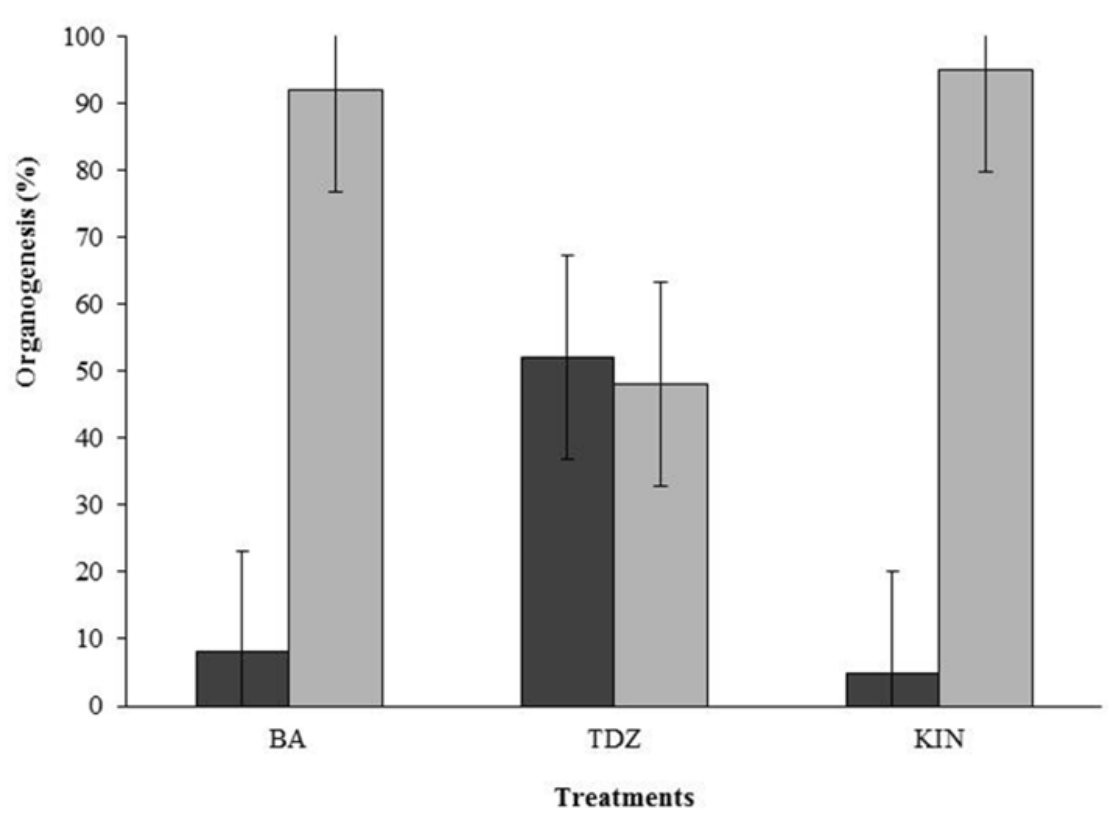

Figure 2. Percentage of direct and indirect organogenesis of Passiflora miniata root explants after 30 days of in vitro culture in media supplemented with BA, TDZ or KIN. Error bars denote the standard error.

After 30 days of culture, regenerated shoots were transferred and cultured in MS medium without plant growth regulators for 90 days (Fig. 1E). Under these conditions, most shoots underwent no further differentiation, and few became plants. The highest percentage of plants and root development were derived from the previous treatment with 6.4 $\mu \mathrm{M} \mathrm{TDZ}$ (Table1). After this period, complete plants were cultivated in substrate under greenhouse conditions. Seedlings were considered acclimatized after 10 days of culture (Fig. 1F). In regeneration systems of Passiflora species, the conversion of adventitious shoots into plants is low $[33,11,12,38]$, and further studies to improve it still needed.

In the present study, we have described a shoot organogenesis-based system for in vitro regeneration of Passiflora miniata, an Amazonia passion fruit species from root explants. We believe that this data may be useful in future research for rapid $P$. miniata micropropagation, conservation and to study such wild Amazonic passion fruit species.

\section{CONCLUSIONS}

The organogenesis-based system was stablished for in vitro regeneration of an Amazonian passion fruit species, P. miniata, using root explants. This explant source showed high regenerative potential under presence of $6.8 \mu \mathrm{M}$ TDZ. 


\section{ACKNOWLEDGMENTS}

The authors would like to thank the CAPES and FAPEMAT for the financial support.

\section{REFERENCES}

1.Montero DA, Meletti LMM, Marques MOM. Fenologia do florescimento e características do perfume das flores de Passiflora quadrangularis L. (maracujá-melão). Rev Brasil de Hort Orn 2013, 19: 99-106.

2.Bernacci LC, Cervi AC, Milward-de-Azevedo MA, Nunes TS, Imig DC, Mezzonato AC. Passifloraceae In: Lista de espécies da flora do Brasil. Jardim Botânico do Rio de Janeiro. 2015. Disponível em: <http://www.floradobrasil.jbri.gov.br/jabot/floradobrasil/FB182>17 mar, 2018.

3. Peixoto, M. Problemas e perspectivas do maracujá ornamental. In: Faleiro, FG, Junqueira, NTV, Braga, MF, (ed.) Maracujá germoplasma e melhoramento genético. Planaltina, DF: Embrapa Cerrados, 2005, p. 458-462.

4. Cerqueira-Silva CBM, Jesus ON, Santos ESL, Corrêa RX, Souza AP. Genetic breeding and diversity of the genus Passiflora: progress and perspectives in molecular and genetic studies. Int $\mathrm{J}$ of Mol Sci 2014, 15, 14122-14152.

5.Amugune NO, Gopalan HNB, BYtebier B. Leaf disc regeneration of passion fruit. African Crop Sci J 1993 1, 99-104.

6. Biasi LA, Falco MC, Rodriguez AP, Mendes BMJ. Organogenesis from internodal segments of yellow passion fruit. Sci Agric 2000, 57, 661-665.

7.Pacheco G, Garcia R, Lugato D, Vianna M, Mansur E. Plant regeneration, callus induction and establishment of cell suspension cultures of Passiflora alata Curtis. Sci Hortic 2012, 144:42-47.

8.Garcia R, Pacheco G, Falcão E, Borges G, Mansur E. Influence of type of explant, plant growth regulators, salt composition of basal medium, and light on callogenesis and regeneration in Passiflora suberosa L. (Passifloraceae). Plant Cell Tiss and Org Cult 2011, 106:47-54.

9. Anand SP, Jayakumar E, Jeyachandran R, Nandagobalan V, Doss A. Direct organogenesis of Passiflora foetida L. through nodal explants. Plant Tiss Cult Biotechnol. 2012, 22:87-91.

10. Shekhawat MS, Kannan N, Manokari M, Ravindran CP. In vitro regeneration of shoots and ex vitro rooting of an important medicinal plant Passiflora foetida $\mathrm{L}$. through nodal segment cultures. $\mathrm{J}$ Genet Eng Biotechnol 2015, 13:209-214.

11. Vieira LM, Rocha DI, Taquetti MF, Silva LC, Campos JMS, Viccini, LF, Otoni WC. In vitro plant regeneration of Passiflora setacea DC (Passifloraceae): the influence of explant type, growth regulators, and incubation conditions. In Vitro Cell Dev Biol Plant 2014, 50:738-745.

12. Rocha DI, Monte-Bello CC, Dornelas MC. Alternative induction of de novo shoot organogenesis or somatic embryogenesis from in vitro cultures of mature zygotic embryos of passion fruit (Passiflora edulis Sims) is modulated by the ratio between auxin and cytokinin in the medium. Plant Cell Tiss Organ Cult 2015, 120:1087-1098.

13. Carvalho PP, Antoniazzi CA, Silva NT, Mikosvki Al, Carvalho IF, Carvalho MLS. Regeneração in vitro de Passiflora miniata Mast. Ornam Hortic 2017, 23:88-95.

14. Silva, CV; Oliveira, LS; Loriato, VAP; Silva, LC; Campos, JMS; Viccini, LF; Oliveira, EJ; Otoni, WC. Organogenesis from root explants of commercial populations of Passiflora edulis Sims and a wild passionfruit species, P. cincinnata Masters. Plant Cell Tiss and Org Cult 2011, 107:407-416. 
15. Rocha DI, Vieira LM, Tanaka, Fao, Silva LC, Otoni WC. Anatomical and ultrastructural analyses of in vitro organogenesis from root explants of commercial passion fruit (Passiflora edulis Sims). Plant Cell Tiss Organ Cult 2012, 111:69-78.

16. Rosa, YBCJ, Bello, CCM, Dornelas, MC. In vitro organogenesis and efficient plant regeneration from root explants of Passiflora suberosa L. (Passifloraceae). In vitro Cell Dev Biol Plant 2016, 52:64-71.

17. Vinocur BV, Carmi T, Altman A, Ziv M. Enhanced bud regeneration in aspen (Populus tremula L.) root cultured in liquid media. Plant Cell Rep 2000, 19:1146-1154.

18. Lombardi, SP, Passos IRS, Nogueira MCS, Appezato-da-Glória B. In vitro shoot regeneration from roots and leaf discs of Passiflora cincinnata Mast. Braz Arch Biol Biotech 2007, 50:239-247.

19. Lim, TK. Passiflora miniata. Edible Medicinal And Non-Medicinal Plants 2012, 4:178-180.

20. Vanderplank, J. Passiflora miniata. Curtis's Bot Magaz 2006, 23:223-230.

21. Ferreira DAT, Sattler MC, Carvalho CR, Clarindo WR. Embryogenic potential of immature zygotic embryos of Passiflora: a new advance for in vitro propagation without plant growth regulators. Plant Cell Tiss and Org Cult 2015, 122:629-638.

22. Reis LB, Silva ML, Lima ABP, Oliveira MLP, Pinto DLP, Lani ERG et al. Agrobacterium rhizogenes-mediated transformation of passionfruit species: Passiflora cincinnata and $P$. edulis flavicarpa. Acta Hortic 2007, 738:425-431.

23.Murashige T, Skoog F. A revised medium for rapid growth and bioassays with tobacco tissue cultures. Physiol Plant 1962, 15:473-497.

24. Ferreira DF. SISVAR: a computer statistical analysis system. Ciência e Agrotecnol 2011, 35:1039-1042.

25. Atta R, Laurens L, Boucheron-Dubuisson E, Guivarch A, Carnero E, Giraudat-Pautot V, et al. Pluripotency of Arabidopsis xylem pericycle underlies shoot regeneration from root and hypocotyl explants grown in vitro. Plant $\mathrm{J} 2009,57: 626-644$.

26. Xing Y, Yu Y, Luo X, Zhang JN, Zhao B, Guo YD. High efficiency organogenesis and analysis of genetic stability of the regenerants in Solanum melongena. Biol Plant 2010; 54:231-236.

27. Yang JL, Seong ES, Kim MJ, Ghimire BK, Kang WH, Yu CY, Li CH. Direct somatic embryogenesis from pericycle cells of broccoli (Brassica oleracea L. var. italica) root explants. Plant Cell Tiss Org Cult 2010; 100:49-58

28. Lombardi SP; Passos, IRS.; Nogueira, MCS; Appezato-da-Glória, B. In vitro shoot regeneration from roots and leaf discs of Passiflora cincinnata Mast. Braz Arch Biol Tech 2007 50:239-247.

29. Rocha DI, Monte-Bello CC, Aizza LCB, Dornelas MC. A passion fruit putative ortholog of the SOMATIC EMBRYOGENESIS RECEPTOR KINASE1 gene is expressed throughout the in vitro de novo shoot organogenesis developmental program. Plant Cell Tiss Organ Cult 2016, 125: 107-117.

30. Skoog F, Miller CO. Chemical regulation of growth and organ formation in plant tissue cultures in vitro. Sym of the Soci for Exp Biol 1957, 11:118-131.

31. Duclercq J, Sangwan-Norreel B, Catterou M, Sangwan RS. De novo shoot organogenesis: from art to science. Trends in Plant Sci 2011, 16:597-606.

32. Xu L, Huang, H. Genetic and epigenetic controls of plant regeneration. Curr Topics in Dev Biol 2014. 108, p.1-

33. Otoni, WC, Pinto, DPL, Rocha, DI, Vieira, LM, Dias, LLC, Silva, ML, Silva, CV, Lani, ERG; Silva, LC, Tanaka, FAO. Organogenesis and somatic embryogenesis in passionfruit (Passiflora spp.). In: 
Aslam, J; Srivastava, OS; Sharma, MP. (eds). Somatic embryogenesis and gene expression, 1st edn. Narosa Publishing House, New Delhi, 2013, pp 1-17.

34. Mok MC, Mok DWS, Armstrong DJ. Cytokinin activity of $N$-phenyl- $N-1$, 2, 3-thidiiazol-5ylurea (TDZ). Phytochem 1982, 21:1509-1511.

35. Lu, CY. The use of thidiazuron in tissue culture. In Vitro Cell Dev Biol Plant. 1993; 29:92-96.

36 Jones M, Yi Z, Murch SJ, Saxena PK. Thidiazuron-induced regeneration of Echinacea purpurea L.: micropropagation in solid and liquid culture systems. Plant Cell Rep 2007, 26:13-19.

37. Novikova Tatyana I; Yulianna Zaytseva G. TDZ-Induced Morphogenesis Pathways in Woody Plant Culture. IN: Thidiazuron: From Urea Derivative to Plant Growth Regulator. Editors: Mohammad Faisal, Naseem Ahmad. Publisher: Springer Nature, 2018, pp 61-94.

38. Antoniazzi CA; Faria RB; Carvalho PP; Mikovski Al; Carvalho IF; Matos EM; Reis, AC; Viccini, LF; Paim Pinto DL; Rocha DI; Otoni WC; Silva ML. In vitro regeneration of triploid plants from mature endosperm culture of commercial passionfruit (Passiflora edulis Sims). Sci Hortic 2018, 238:408-415.

(C) 2018 by the authors. Submitted for possible open access publication under the terms and conditions of the Creative Commons Attribution (CC BY NC) license (https://creativecommons.org/licenses/by-nc/4.0/). 